\title{
Association Between Fasting Plasma Triglycerides, All-Cause and Cardiovascular Mortality in Czech Population. Results From the HAPIEE Study
}

\author{
H. PIKHART ${ }^{1}$, J. A. HUBÁČEK ${ }^{2}$, A. PEASEY ${ }^{1}$, R. KUBÍNOVÁ ${ }^{3}$, M. BOBÁK ${ }^{1}$ \\ ${ }^{1}$ Department of Epidemiology and Public Health, University College London, London, United \\ Kingdom, ${ }^{2}$ Laboratory for Atherosclerosis Research, Center for Experimental Medicine, Institute \\ for Clinical and Experimental Medicine, Prague, Czech Republic, ${ }^{3}$ National Institute of Public \\ Health, Prague, Czech Republic
}

Received September 3, 2015

Accepted September 17, 2015

\section{Summary}

Dyslipidemia is the risk factor of cardiovascular disease, but the relationship between the plasma triglyceride (TG) levels and total/cardiovascular mortality has not yet been analyzed in Slavs. The aim of our study was to analyze the association between the fasting TG levels and all-cause/cardiovascular mortality. We have examined 3,143 males and 3,650 females, aged 58.3 \pm 7.1 years. 729 deaths (274 cardiovascular deaths) have been registered during up to 11.8 years of follow-up. Age-sex adjusted all-cause mortality was higher in individuals with TG values 3.01-4.00 $\mathrm{mmol} / \mathrm{l}$ (HR 1.37, $95 \% \mathrm{CI} 1.02-1.83, \mathrm{P}=0.035)$ and over 4.00 $\mathrm{mmol} / \mathrm{l}$ (HR 1.66, $95 \%$ CI 1.21-2.27, $\mathrm{P}=0.002$ ) when compared with a reference group (TG $1.41-1.80 \mathrm{mmol} / \mathrm{l}$ ). Elevated risk remains significant when adjusted for education, marital status and unemployment. When further adjusted for smoking, BMI and dyslipidemia interventions, HR for those in above $4.00 \mathrm{mmol} / \mathrm{l}$ group decreased $(1.42, \mathrm{P}=0.04)$. The results have been similar when cardiovascular mortality has been examined, however, results reached statistical significance only for the TG over $4.0 \mathrm{mmol} / \mathrm{l} \quad(P=0.028)$. Our results confirmed that enhanced plasma levels of plasma triglycerides are dose dependently associated with increased risk of all-cause mortality, however, it seems that individuals with TG values $1.8-3.0 \mathrm{mmol} / \mathrm{l}$ are not in higher risk of death.

\section{Key words}

Triglycerides • Risk factor • All-cause mortality • Cardiovascular mortality

\section{Corresponding author}

H. Pikhart, Research Department of Epidemiology and Public Health, University College London, 1-19 Torrington Place, London WC1E 6BT, UK. Fax: 004420 78130280. E-mail: h.pikhart@ucl.ac.uk

\section{Introduction}

There is wide range of risk factors associated with increased risk of cardiovascular disease and mortality (some of them summarized by Hopkins and Williams 1981). Elevated levels of plasma lipids are listed among the seven major risk factors (together with smoking, obesity, hypertension, diabetes, low physical activity, and abundant alcohol intake) which are responsible for the majority of cases of cardiovascular and, more interestingly, all-cause mortality in industrialized countries.

Despite decades of research, there are still many inconsistencies in estimation of risk values and we are not able to predict mortality and morbidity with reasonable accuracy. Interestingly, the importance of individual risk factors has not been examined, confirmed and verified in all geographic regions. This is particularly true for the former communist countries with Slavonic population. As suggested before, the distribution and the importance of some risk factors can differ not only between the ethnic groups (Kanjilal et al. 2008), but also between the geographic regions or countries (Petursson et al. 2012). These differences mostly reflect the different environmental conditions, environmental factors and 
different genetic background of such populations.

High plasma lipids, or dyslipidemia (DL) are at the top of considered risk factors. Dyslipidemia is based on the measurements of fasting plasma lipids although no clear and universal general definition is presented in guidelines (Ray et al. 2014). General recommendations usually do not use absolute values, but suggest "target values" for different types of individuals. Generally, values used for DL definition are plasma total cholesterol over $5.0 \mathrm{mmol} / \mathrm{l}$, triglycerides over $1.8 \mathrm{mmol} / \mathrm{l}$ or $\mathrm{HDL}$ cholesterol below $1.0 \mathrm{mmol} / \mathrm{l}$ for males and below $1.2 \mathrm{mmol} / \mathrm{l}$ for females (Soska et al. 2013).

Definition based on plasma total cholesterol is still used despite the fact that there is increasing level of uncertainty about the mortality risks associated with elevated plasma levels of total cholesterol (for example Matsuzaki et al. 2002, Ravnskov 2009, Langsted et al. 2011, Petursson et al. 2012, Tamosiunas et al. 2014, Hubacek 2015) and many studies show rather protective effect of slightly elevated plasma cholesterol, especially in elderly (over 50 or 55 years) individuals. Furthermore, recent Mendelian randomisation study argued against HDL-cholesterol being a causal risk factor of cardiovascular disease (Haase et al. 2012). Thus plasma triglycerides seem to remain last important factor, defining dyslipidemia, which should be taken into account (Miller et al. 2011, Kohli and Cannon 2012).

In this paper we conducted an analysis to evaluate the role of plasma triglyceride levels as a risk factor for allcause and cardiovascular mortality in Central European Slavonic population from the Czech Republic.

\section{Methods}

The analysis has been performed on 6,793 individuals with TG and mortality data (3,143 men and 3,650 women, mean age $58.3 \pm 7.1$ years at the time of the baseline examination) examined in the Health, Alcohol and Psychosocial factors In Eastern Europe (HAPIEE) study. Although the HAPIEE is an international study, only subjects from the Czech Republic (collected at six centers - Havirov/Karvina, Hradec Kralove, Jihlava, Kromeriz, Liberec and Usti nad Labem) have been included in this report. All individuals were self-reported Caucasians. The HAPIEE study was approved by ethics committees at University College London and Czech National Institute of Public Health. All participants gave informed consent. The protocol of the selection and examination was described in detail by Peasey et al.
(2006) and by Hubacek et al. (2011, 2014).

Deaths were obtained from the National death register. Follow up was between 8.6 and 11.8 years among those surviving till the end of study period; mean follow-up being 9.85 years. Plasma triglycerides were measured enzymatically in the Regional Lipid Reference Center, with a Roche COBAS MIRA autoanalyzer (https://usdiagnostics.roche.com/products/11877771216/ PARAM67/overlay.html).

In order to assess the association between the plasma TG levels and all-cause mortality, fasting plasma TG was categorized into following groups: less than $1.00 \mathrm{mmol} / \mathrm{l} ; \quad 1.01-1.40 \mathrm{mmol} / \mathrm{l} ; \quad 1.41-1.80 \mathrm{mmol} / \mathrm{l}$; 1.81-2.40 mmol/1; 2.41-3.00 mmol/1; 3.01-4.00 mmol/l, and over $4.01 \mathrm{mmol} / \mathrm{l}$.

Based on the recommendations used for the population-based MONICA study (Cifkova et al. 2010) a group of individuals with plasma TG values between $1.41-1.80 \mathrm{mmol} / \mathrm{l}$ has been used as a reference category, with HR 1.00 .

Cox regression was used to investigate the association between TG and mortality. The estimated hazard ratios (HR) indicate the change in mortality between reference category and other categories of TG. The analysis has been conducted in several steps. Firstly, the association between TG and all-cause mortality has been adjusted for sex and age, as two major nonmodifiable factors affecting plasma TG values. Furthermore, the association was additionally adjusted for education, marital status, employment status (step 2), smoking status, body mass index (BMI, calculated as $\mathrm{kg} / \mathrm{m}^{2}$ ) (step 3), past knowledge of high total cholesterol (including individuals treated for dyslipidemia pharmacologically and/or due to the life style interventions) (step 4). Finally, as plasma TG levels correlate with HDL-cholesterol levels, an additional adjustment has been performed for HDL-cholesterol in all steps of the analysis.

The analysis was then repeated using CVD cause-specific mortality as further outcome of interest.

Stata v.13 has been used for all statistical analyses (StataCorp, College Station, TX, USA).

\section{Results}

General characteristics of the examined individuals are summarized in Table 1. Mean fasting plasma TG were $2.15 \mathrm{mmol} / \mathrm{l}$ in males and $1.72 \mathrm{mmol} / \mathrm{l}$ in females. 
During the follow up, 729 (10.7\% of analytical sample) have died. 274 deaths $(4.0 \%$ of all individuals, $37.6 \%$ of all deaths) were due to cardiovascular causes.

Table 1. General characteristics of the examined individuals.

\begin{tabular}{lc}
\hline$N$ & 6,793 \\
\% of males & 46.3 \\
Age (years) & $58.3 \pm 7.1$ \\
TG levels (mmol/l) & $1.92 \pm 1.35$ \\
Total cholesterol levels (mmol/l) & $5.73 \pm 1.05$ \\
BMI $\left(\mathrm{kg} / \mathrm{m}^{2}\right)$ & $27.5 \pm 4.1$ \\
Ever smokers prevalence (\%) & 56.2 \\
Diabetes prevalence (\%) & 11.3 \\
\hline
\end{tabular}

Values for continuous variables are given as mean \pm SD.
In general, similar to other populations, our results suggest the association between high plasma triglyceride levels and both all-cause mortality (Table 2) and cardiovascular mortality (Table 3 ).

Table 2 shows the results for all-cause mortality. All-cause mortality was similar in subgroups from the lowest values of TG (below $1.00 \mathrm{mmol} / \mathrm{l}$ ) to the subgroup with values between 2.41-3.00 $\mathrm{mmol} / \mathrm{l}$, and this fact was not influenced by further adjustments. Individuals with plasma TG values between 3.01-4.00 mmol/1 and over $4.00 \mathrm{mmol} / \mathrm{l}$ have elevated risk of mortality by $37 \%$ $(\mathrm{P}=0.035)$ and $66 \%(\mathrm{P}=0.002)$, respectively, when age and sex adjusted. Further adjustment reduced this elevation and only those with TG levels above $4.00 \mathrm{mmol} / \mathrm{l}$ had significantly higher risk of death in fully adjusted model.

Table 2. HR (95\% CI) of all-cause mortality in different categories of plasma triglycerides.

\begin{tabular}{|c|c|c|c|c|c|}
\hline \multirow[b]{2}{*}{ Triglycerides } & \multirow[b]{2}{*}{$\begin{array}{c}\mathrm{N} \text { total } \\
\text { (N deaths) }\end{array}$} & \multicolumn{4}{|c|}{ Adjustment } \\
\hline & & Age and sex & $\begin{array}{l}\text { Age, sex, education, } \\
\text { marital status, } \\
\text { employment status }\end{array}$ & $\begin{array}{l}\text { Age sex, education, } \\
\text { marital status, } \\
\text { employment status } \\
\text { smoking, BMI }\end{array}$ & $\begin{array}{l}\text { Age sex, education, } \\
\text { marital status, } \\
\text { employment status } \\
\text { smoking, BMI, past } \\
\text { knowledge of high TG }\end{array}$ \\
\hline Below 1.00 & $1262(131)$ & $1.06(0.81-1.37)$ & $1.11(0.85-1.44)$ & $1.15(0.88-1.51)$ & $1.13(0.86-1.48)$ \\
\hline $1.01-1.40$ & $1186(103)$ & $1.10(0.87-1.38)$ & $1.11(0.88-1.41)$ & $1.13(0.89-1.44)$ & $1.11(0.87-1.42)$ \\
\hline $1.41-1.80$ & $1620(162)$ & 1.00 (ref) & 1.00 (ref) & 1.00 (ref) & 1.00 (ref) \\
\hline $1.81-2.40$ & $1249(140)$ & $1.11(0.88-1.41)$ & $1.09(0.85-1.39)$ & $1.05(0.82-1.34)$ & $1.03(0.81-1.32)$ \\
\hline $2.41-3.00$ & $629(67)$ & $1.01(0.75-1.35)$ & $0.98(0.72-1.33)$ & $0.87(0.64-1.19)$ & $0.84(0.62-1.16)$ \\
\hline \multirow[t]{2}{*}{$3.01-4.00$} & 468 (69) & $1.37(1.02-1.83)$ & $1.35(1.00-1.82)$ & $1.24(0.91-1.68)$ & $1.25(0.92-1.69)$ \\
\hline & & $\mathrm{P}=0.035$ & $\mathrm{P}=0.049$ & $\mathrm{P}=0.166$ & $\mathrm{P}=0.160$ \\
\hline \multirow[t]{2}{*}{ Above 4.01} & $379(57)$ & $1.66(1.21-2.27)$ & $1.58(1.14-2.19)$ & $1.40(1.02-1.96)$ & $1.42(1.02-1.98)$ \\
\hline & & $\mathrm{P}=0.002$ & $\mathrm{P}=0.004$ & $\mathrm{P}=0.046$ & $\mathrm{P}=0.039$ \\
\hline
\end{tabular}

Further adjustment for HDL-cholesterol levels did not change the results with one minor exception: fully adjusted model becomes non-significant at $\mathrm{P}=0.052$.

Similar trends have been observed for cardiovascular mortality (Table 3 ). Here, the risk of death after age and sex adjustment was 1.30 (n.s.) for those in $3.01-4.00 \mathrm{mmol} / 1$ group and $1.66(\mathrm{P}=0.026)$ for those in $4.00+\mathrm{mmol} / 1$ group. While the magnitude of the effect was similar to all-cause mortality, majority of the results have been (borderline) non-significant due to lower number of cases and lower analytical power.

\section{Discussion}

In our study, we have shown that elevated plasma levels of triglycerides are associated with increased risk of both all-cause and, in some extent, cardiovascular mortality in Central European Slavonic population from the Czech Republic. In the case of all-cause mortality this finding was documented on crude data as well as after the adjustment for sex, age, education, marital status, smoking, BMI values and past 
Table 3. HR (95 \% CI) of cardiovascular mortality in different categories of plasma triglycerides.

\begin{tabular}{|c|c|c|c|}
\hline \multirow{2}{*}{ Triglycerides } & \multirow[b]{2}{*}{$\begin{array}{c}\mathrm{N} \text { total } \\
(\mathrm{N} \text { deaths })\end{array}$} & \multicolumn{2}{|r|}{ Adjustment } \\
\hline & & Age and sex & $\begin{array}{c}\text { Age sex, education, marital status, employment status } \\
\text { smoking, BMI, past knowledge of high TG }\end{array}$ \\
\hline Below 1.00 & $1262(48)$ & $0.87(0.59-1.29)$ & $0.96(0.64-1.45)$ \\
\hline $1.01-1.40$ & $1186(32)$ & $1.12(0.81-1.55)$ & $1.10(0.78-1.56)$ \\
\hline $1.41-1.80$ & $1620(63)$ & 1.00 (ref) & 1.00 (ref) \\
\hline $1.81-2.40$ & $1249(49)$ & $0.96(0.67-1.36)$ & $0.86(0.59-1.24)$ \\
\hline $2.41-3.00$ & $629(31)$ & $0.94(0.61-1.44)$ & $0.73(0.46-1.17)$ \\
\hline $3.01-4.00$ & $468(29)$ & $1.30(0.85-1.98)$ & $1.14(0.73-1.79)$ \\
\hline Above 4.01 & $379(22)$ & $\begin{array}{c}1.66(1.06-2.61) \\
\mathrm{P}=0.028\end{array}$ & $1.32(0.81-2.14)$ \\
\hline
\end{tabular}

Further adjustment for HDL-cholesterol levels virtually did not change the results.

respondent's knowledge about high cholesterol levels including respondent being on dyslipidemic treatment or dietary intervention. It needs to be further mentioned that almost all individuals treated for dyslipidemia are on low prescribed doses (10-20 mg per day) of statins and triglyceride lowering effect of statins is not large clinical trials reported TG lowering effect of statins to be between 10 and $20 \%$, and in general clinical praxis, $5-10 \%$ decrease is usually achieved. Our results underline the importance of the use of the plasma TG values for estimating risk of mortality in Central European Slavonic population.

Results in our study are similar to those obtained in recently published large meta-analysis including more than 330,000 individuals (with 58,000 cases of all-cause mortality) from 61 studies (Liu et al. 2013). They have used TG between 1.01 and $1.65 \mathrm{mmol} / 1$ (90-149 mg/dl, respectively) as reference category, and reported relative risk for all-cause mortality being 1.09 and 1.20, respectively, in categories 1.65-2.24 mmol/l and over $2.25 \mathrm{mmol} / \mathrm{l}$. The analysis of cardiovascular mortality revealed similar results. Interestingly, there were no significant differences between ethnic groups and regions as European, American and Asia/Pacific regions have been compared.

In contrast to the previously published studies and meta-analyses, we have detected higher borderline values as those increasing the risk. In Czechs, values higher than $3.0 \mathrm{mmol} / \mathrm{l}$ have been detected as risky, but the risk associated with these values is higher than in previously published studies. In five subgroups between "below $1 \mathrm{mmol} / \mathrm{l}$ " and "2.41-3.00 mmol/l", there were no differences in risk of all-cause, or CVD mortality. Age and sex adjusted HRs have been between 0.87 and 1.12 in these categories, with no observed linear association. This shift could be explained by the fact, that considerable part of studies included in the meta-analysis have started in last millennium and different environmental exposures (such as consumed diet) could be expected.

Some mechanisms of the association between plasma TG levels and increased morbidity and mortality have been previously discussed (Miller et al. 2011, Kohli and Cannon 2013, Kackov et al. 2013, Varbo et al. 2013, Borén et al. 2014). Generally, they focused on some distinct aspects of possible link rather than covering possible complexity of the association. One such possible explanation is, for example, the association between plasma triglycerides and higher oxidative stress/reactive oxygen species (ROS) as shown in animal models (PérezRodríguez et al. 2015) and in humans (Yubero-Serrano et al. 2013).

Our study focused on all-cause mortality from several reasons. Firstly, general life expectancy is of major interest in general population. Secondly, the reduction of the incidence of one type of cause-specific mortality without increase in life expectancy would only mean redistribution in causes of death. Thirdly, the number of deaths related to specific diagnoses (cardiovascular, cancer and "other") is still relatively low and analysis of cause-specific mortality has limited power.

Finally, previous studies suggested, that the association between high plasma TG levels and mortality is similar for total and cardiovascular mortality (Liu et al. 
2013). Other studies focusing on the role of triglycerides showed similar associations with other causes of disease. Borena et al. (2011) have demonstrated increased risk of different types of cancer in individuals with higher TG values. The relative risk associated with increased TG values was almost identical as in the case of cardiovascular mortality described by Liu et al. (2013). Similarly, the risk of kidney disease (Navaneethan et al. 2012) has been associated with plasma TG values. Widely discussed, but with inconsistent results is also the association between plasma TG levels and suicides (Ainiyet and Rybakowski 2014, Baek et al. 2014, Chang et al. 2012). Elevated plasma triglycerides have also been shown to predict all-cause mortality in patients with type 2 diabetes mellitus (Miselli et al. 2014), and have also been risk for the development of acute pancreatitis (Lindkvist et al. 2012).

Several strengths of our study should be mentioned. Firstly, it is based on the general population sample, thus the risk of selection bias is small. Furthermore, the relatively long follow-up in our study (over 9 years on average) reduces possibility of reverse causation (Szklo and Nieto 2006), and further exclusion of deaths in the first two years of the follow-up did not change the results significantly. Finally, the data for study individuals have been collected within the short time period and this fact minimizes the risk that some environmental changes during time of data collection influence these findings.
We conclude that high levels of plasma triglycerides are associated with increased total mortality risk. This increased risk is associated with fasting plasma triglyceride levels over $3.0 \mathrm{mmol} / \mathrm{l}$. This means that about $15 \%$ of the population at age over 50 years is under increased risk of death because of the higher plasma TG concentrations.

\section{Conflict of Interest}

There is no conflict of interest.

\section{Acknowledgements}

This work was supported by the project (Ministry of Health, Czech Republic) for development of research organization 00023001 (IKEM, Prague, Czech Republic) - Institutional Support. The Centre for Experimental Medicine (IKEM) received financial support from the European Commission within the Operational Programme, Prague - Competitiveness; project "CEVKOON" (\#CZ.2.16/3.1.00/22126). The HAPIEE study was supported by Wellcome Trust "Determinants of Cardiovascular Diseases in Eastern Europe: Longitudinal follow-up of a multi-centre cohort study" (The HAPIEE Project) (Reference number 081081/Z/06/Z); MacArthur Foundation "Health and Social Upheaval (a research network)"; and US National Institute on Aging "Health disparities and aging in societies in transition (the HAPIEE study)" (Grant number 1R01 AG23522).

\section{References}

AINIYET B, RYBAKOWSKI JK: Suicidal behavior in schizophrenia may be related to low lipid levels. Med Sci Monit 20: 1486-1490, 2014.

BAEK JH, KANG ES, FAVA M, MISCHOULON D, NIERENBERG AA, YU BH, LEE D, JEON HJ: Serum lipids, recent suicide attempt and recent suicide status in patients with major depressive disorder. Prog Neuropsychopharmacol Biol Psychiatry 51: 113-118, 2014.

BORÉN J, MATIKAINEN N, ADIELS M, TASKINEN MR: Postprandial hypertriglyceridemia as a coronary risk factor. Clin Chim Acta 431: 131-142, 2014.

BORENA WST, JONSSON H, STROHMAIER S, NAGEL G, BJØRGE T, MANJER J, HALLMANS G, SELMER R, ALMQUIST M, HÄGGSTRÖM C, ENGELAND A, TRETLI S, CONCIN H, STRASAK A, STATTIN P, ULMER H: Serum triglycerides and cancer risk in the metabolic syndrome and cancer (Me-Can) collaborative study. Cancer Causes Control 22: 291-299, 2011.

CHANG SS, WEN CP, TSAI MK, LAWLOR DA, YANG YC, GUNNELL D: Adiposity, its related biologic risk factors, and suicide: a cohort study of 542,088 taiwanese adults. Am J Epidemiol 175: 804-815, 2012.

CÍFKOVÁ R, SKODOVÁ Z, BRUTHANS J, ADÁMKOVÁ V, JOZÍFOVÁ M, GALOVCOVÁ M, WOHLFAHRT P, KRAJCOVIECHOVÁ A, POLEDNE R, STÁVEK P, LÁNSKÁ V: Longitudinal trends in major cardiovascular risk factors in the Czech population between 1985 and 2007/8. Czech MONICA and Czech post-MONICA. Atherosclerosis 211: 676-681, 2010. 
HAASE CL, TYBJÆRG-HANSEN A, QAYYUM AA, SCHOU J, NORDESTGAARD BG, FRIKKE-SCHMIDT R: LCAT, HDL cholesterol and ischemic cardiovascular disease: a Mendelian randomization study of HDL cholesterol in 54,500 individuals. J Clin Endocrinol Metab 97: E248-E256, 2012.

HOPKINS PN, WILLIAMS RR: A survey of 246 suggested coronary risk factors. Atherosclerosis 40: 1-52, 1981.

HUBACEK JA: High plasma cholesterol is not associated with higher total mortality (in Czech). Hypert Kardiovask Prevence 1: 58-62, 2015.

HUBÁČEK JA, PIKHART H, PEASEY A, KUBÍNOVÁ R, BOBÁK M: FTO variant, energy intake, physical activity and basal metabolic rate in Caucasians. The HAPIEE study. Physiol Res 60: 175-183, 2011.

HUBACEK JA, PEASEY A, KUBINOVA R, PIKHART H, BOBAK M: The association between APOA5 haplotypes and plasma lipids is not modified by energy or fat intake: the Czech HAPIEE study. Nutr Metab Cardiovasc Dis 24: 243-247, 2014.

KACKOV S, SIMUNDIC AM, NIKOLAC N, CELAP I, DUKIC L, RUZIC D, BILUSIC M: The effect of high-calorie meal consumption on oxidative stress and endothelial dysfunction in healthy male adults. Physiol Res 62: 643-652, 2013.

KANJILAL S, RAO VS, MUKHERJEE M, NATESHA BK, RENUKA KS, SIBI K, IYENGAR SS, KAKKAR VV: Application of cardiovascular disease risk prediction models and the relevance of novel biomarkers to risk stratification in Asian Indians. Vasc Health Risk Manag 4: 199-211, 2008.

KOHLI P, CANNON CP: Triglycerides: how much credit do they deserve? Med Clin North Am 96: 39-55, 2012.

LANGSTED A, FREIBERG JJ, TYBJAERG-HANSEN A, SCHNOHR P, JENSEN GB, NORDESTGAARD BG: Nonfasting cholesterol and triglycerides and association with risk of myocardial infarction and total mortality: the Copenhagen City Heart Study with 31 years of follow-up. J Intern Med 270: 65-75, 2011.

LINDKVIST B, APPELROS S, REGNÉR S, MANJER J: A prospective cohort study on risk of acute pancreatitis related to serum triglycerides, cholesterol and fasting glucose. Pancreatology 12: 317-324, 2012.

LIU J, ZENG FF, LIU ZM, ZHANG CX, LING WH, CHEN YM: Effects of blood triglycerides on cardiovascular and all-cause mortality: a systematic review and meta-analysis of 61 prospective studies. Lipids Health Dis 12: $159,2013$.

MATSUZAKI M, KITA T, MABUCHI H, MATSUZAWA Y, NAKAYA N, OIKAWA S, SAITO Y, SASAKI J, SHIMAMOTO K, ITAKURA H; J-LIT STUDY GROUP, JAPAN LIPID INTERVENTION TRIAL: Large scale cohort study of the relationship between serum cholesterol concentration and coronary events with lowdose simvastatin therapy in Japanese patients with hypercholesterolemia. Circ J 66: 1087-1095, 2002.

MILLER M, STONE NJ, BALLANTYNE C, BITTNER V, CRIQUI MH, GINSBERG HN, GOLDBERG AC, HOWARD WJ, JACOBSON MS, KRIS-ETHERTON PM, LENNIE TA, LEVI M, MAZZONE T, PENNATHUR S; AMERICAN HEART ASSOCIATION CLINICAL LIPIDOLOGY, THROMBOSIS, AND PREVENTION COMMITTEE OF THE COUNCIL ON NUTRITION, PHYSICAL ACTIVITY, AND METABOLISM; COUNCIL ON ARTERIOSCLEROSIS, THROMBOSIS AND VASCULAR BIOLOGY; COUNCIL ON CARDIOVASCULAR NURSING; COUNCIL ON THE KIDNEY IN CARDIOVASCULAR DISEASE: Triglycerides and cardiovascular disease: a scientific statement from the American Heart Association. Circulation 123: 2292-2333, 2011.

MISELLI MA, NORA ED, PASSARO A, TOMASI F, ZULIANI G: Plasma triglycerides predict ten-years all-cause mortality in outpatients with type 2 diabetes mellitus: a longitudinal observational study. Cardiovasc Diabetol 13: 135, 2014.

NAVANEETHAN SD, SCHOLD JD, ARRIGAIN S, THOMAS G, JOLLY SE, POGGIO ED, SCHREIBER MJ JR, SARNAK MJ, NALLY JV JR: Serum triglycerides and risk for death in Stage 3 and Stage 4 chronic kidney disease. Nephrol Dial Transplant 27: 3228-3234, 2012.

PEASEY A, BOBAK M, KUBINOVA R, MALYUTINA S, PAJAK A, TAMOSIUNAS A, PIKHART H, NICHOLSON A, MARMOT M: Determinants of cardiovascular disease and other non-communicable diseases in Central and Eastern Europe: rationale and design of the HAPIEE study. BMC Public Health 6: 255, 2006.

PÉREZ-RODRÍGUEZ L, ROMERO-HARO AA, STERNALSKI A, MURIEL J, MOUGEOT F, GIL D, ALONSOALVAREZ C: Measuring oxidative stress: the confounding effect of lipid concentration in measures of lipid peroxidation. Physiol Biochem Zool 88: 345-351, 2015. 
PETURSSON H, SIGURDSSON JA, BENGTSSON C, NILSEN TI, GETZ L: Is the use of cholesterol in mortality risk algorithms in clinical guidelines valid? Ten years prospective data from the Norwegian HUNT 2 study. $J$ Eval Clin Pract 18: 159-168, 2012.

RAVNSKOV U: Cholesterol was healthy in the end. World Rev Nutr Diet 100: 90-109, 2009.

RAY KK, KASTELEIN JJ, BOEKHOLDT SM, NICHOLLS SJ, KHAW KT, BALLANTYNE CM, CATAPANO AL, REINER Ž, LÜSCHER TF: The ACC/AHA 2013 guideline on the treatment of blood cholesterol to reduce atherosclerotic cardiovascular disease risk in adults: the good the bad and the uncertain: a comparison with ESC/EAS guidelines for the management of dyslipidaemias 2011. Eur Heart J 35: 960-968, 2014.

SOŠKA V, VAVERKOVÁ H, VRÁBLÍK M, BLÁHA V, CÍFKOVÁ R, FREIBERGER T, KRAML P, PIŤHA J, ROSOLOVÁ H, STULC T, URBANOVÁ Z: Opinion of the Czech Atherosclerosis Society's committee (CSAT) on the ESC/EAS guidelines related to the diagnostics and treatment of dyslipidemias issued in 2011 (in Czech) Vnitr Lek 59: 120-126, 2013.

SZKLO M, NIETO FJ: Epidemiology: Beyond the Basics. Jones and Bartlett Publishers, Sudbury, MA, 2006.

TAMOSIUNAS A, LUKSIENE D, BACEVICIENE M, BERNOTIENE G, RADISAUSKAS R, MALINAUSKIENE V, KRANCIUKAITE-BUTYLKINIENE D, VIRVICIUTE D, PEASEY A, BOBAK M: Health factors and risk of all-cause, cardiovascular, and coronary heart disease mortality: findings from the MONICA and HAPIEE studies in Lithuania. PLoS One 9: e114283, 2014.

VARBO A, BENN M, TYBJÆRG-HANSEN A, JØRGENSEN AB, FRIKKE-SCHMIDT R, NORDESTGAARD BG: Remnant cholesterol as a causal risk factor for ischemic heart disease. $J$ Am Coll Cardiol 61: 427-436, 2013.

YUBERO-SERRANO EM, DELGADO-LISTA J, PEÑA-ORIHUELA P, PEREZ-MARTINEZ P, FUENTES F, MARIN C, TUNEZ I, TINAHONES FJ, PEREZ-JIMENEZ F, ROCHE HM, LOPEZ-MIRANDA J: Oxidative stress is associated with the number of components of metabolic syndrome: LIPGENE study. Exp Mol Med 45: e28, 2013. 